\title{
Effect of Different Chlorine Sources on the Formation of 3-Monochloro-1,2-Propanediol and 2-Monochloro-1,3- Propanediol Fatty Acid Esters during Frying
}

\author{
Erzsébet Bognár ${ }^{1 *}$, Gabriella Hellner², Andrea Radnóti², László Somogyi1 ${ }^{1}$ Zsolt Kemény² \\ 1 Department of Grain and Industrial Plant Processing, Faculty of Food Science, Szent István University, \\ H-1118 Budapest, Villányi út 29-43, Hungary \\ 2 Bunge EMEA Katalin Kővári R\&D Centre, H-1097 Budapest, Illatos út 38, Hungary \\ * Corresponding author, e-mail: zsofi.bognar@outlook.hu
}

Received: 02 April 2019, Accepted: 22 July 2019, Published online: 19 September 2019

\begin{abstract}
Several studies indicated that chlorine salts provoke 3-monochloro-1,2-propanediol fatty acid esters (3-MCPD-FE) and 2-monochloro-1,3- propanediol fatty acid esters (2-MCPD-FE) formation in oils during frying. The amount of MCPD strongly depends on the type and the amount of chlorine salt. Food raw materials, additives themselves may contain several chlorine compounds, providing precursors for 2- and 3-MCPD-FE formation during frying. Then, the fat uptake can cause measurable concentrations in the fried food as well. This paper aims at screening chlorine compounds occurring in food industry. Influence of sodium chloride $(\mathrm{NaCl})$, potassium chloride $(\mathrm{KCl})$, calcium chloride $\left(\mathrm{CaCl}_{2}\right)$, ferric chloride $\left(\mathrm{FeCl}_{3}\right)$ and ammonium chloride $\left(\mathrm{NH}_{4} \mathrm{Cl}\right)$ on the formation of MCPD-FE was investigated, mimicking frying conditions (175-180 ${ }^{\circ} \mathrm{C}$, atmospheric pressure), applying high oleic sunflower oil as frying medium. 2-MCPD-FE and 3-MCPD-FE were determined by using an indirect method based on alkaline-catalyzed transesterification and GC-MS analysis. As expected, the reference sample without using any chlorine salt resulted only slight increase in 3-MCPD-FE concentration, and no increase in 2-MCPD-FE concentration. In case of the stable salts minor formation was observed. At as high as $3 \%$ dosage of $\mathrm{NaCl}$ and $\mathrm{KCl} 1.6$ and $2.4 \mathrm{mg} / \mathrm{kg}$ 3-MCPD-FE generated, respectively. Adding $\mathrm{CaCl}_{2}, \mathrm{NH}_{4} \mathrm{Cl}_{\text {and }} \mathrm{FeCl}{ }_{3}$ resulted in very strong MCPD-FE formation by both isomers (2- and 3-MCPD-FE) in this increasing order. $0.1 \% \mathrm{FeCl}_{3}$ generated $70 \mathrm{mg} / \mathrm{kg}$ 2-MCPD-FE and $238 \mathrm{mg} / \mathrm{kg}$ 3-MCPD-FE by the end of 8-hour heating.
\end{abstract}

Keywords

3-MCPD-FE, 2-MCPD-FE, chlorine salts, frying, high oleic sunflower oil

\section{Introduction}

3-MCPD-FE (3-monochloro-1,2-propanediol fatty acid esters) and 2-MCPD-FE (2-monochloro-1,3-propanediol fatty acid esters) are food-borne contaminants, formed in fat containing food and food ingredients during high temperature thermal treatment. Free 3-MCPD was classified by International Agency for Research on Cancer (IARC) as possibly carcinogenic to humans - category 2B [1]. Tolerable Daily Intake (TDI) and Provisional Maximum Tolerable Daily Intake (PMTDI) values for free 3-MCPD have been defined [2, 3]. The current TDI by EFSA (European Food Safety Authority) is $2 \mu \mathrm{g} / \mathrm{kg}$ body weight/ day [4]. The PMTDI determined by the Joint FAO/WHO Expert Committee on Food Additives (JECFA) is $4 \mu \mathrm{g} / \mathrm{kg}$ body weight/day since 2017 [5]. Although 3-MCPD occurs in ester bound with fatty acids, according to previous studies 3-MCPD is released during digestion by enzymatic hydrolysis from their esters [6]. Currently, 2-MCPD and 2-MCPD-FE are not yet classified in terms of carcinogenicity. EFSA has identified a particular need for research on relevant long-term studies and on mechanisms of toxicity of 2-MCPD and their fatty acid esters because there is a limited amount of data available on their toxicity [7].

The presence of 3-MCPD was first reported in acid-hydrolyzed vegetable proteins [8], and currently, the level of free 3-MCPD is regulated only in acid-hydrolyzed vegetable protein and soy sauces, with maximum permitted level $0.02 \mathrm{mg} / \mathrm{kg}$ [9]. EFSA has decided to re-open the assessment of 3-MCPD, because of the divergences in opinions between the JECFA and the EFSA. The appropriate regulatory measures will be taken based on the outcome of the 
assessment [10]. According to the literature data [11-13], 3-MCPD-FE occur in other foods beyond acid-hydrolyzed vegetable protein and soy sauces, for example in cooking oils, fried potatoes, in roasted and cooked meats, snacks, and practically all thermal-treated products that contain fat. During vegetable oil refining 3-MCPD-FE form in the step of deodorization conducted at high temperature (200$\left.275^{\circ} \mathrm{C}\right)$ [14-16].

In previous studies the formation of 3-MCPD-FE was reported during domestic cooking steps, as well [17-19]. Deep-fat frying is conducted typically at temperature between $150-180{ }^{\circ} \mathrm{C}$. However a serial of complex reactions such as oxidation, hydrolysis, isomerization, and polymerization take place during this process, which result various reaction products. These compounds are present in both frying oil and fried food, as well [20]. Moreover this temperature fulfils the condition for 3-MCPD-FE formation, which starts at $140{ }^{\circ} \mathrm{C}$ [21]. Additionally the presence of chlorine-containing compounds and water is provided by their migration from the object fried in the oil, both of them affect the reaction $[22,23]$. These chlorine sources are organic or inorganic, and they are in low concentration in food, but this level might be enough for formation of MCPD-FE.

For determination of MCPD-FE a number of analytical methods have been developed, they can be divided into two main groups: direct and indirect methods. With direct quantification methods, individual 2- and 3-MCPD esters are determined, and these methods are mainly based on liquid chromatography-mass spectrometry (LC-MS), and enlarged number of reference compounds and internal standards are required [24, 25]. Additionally the detection limits are higher for individual esters than for indirect method because latter is based on conversion of all of 2- or 3-MCPD-FE into free 2- or 3-MCPD which is than isolated, derivatised, chromatographically separated and quantified. The result is expressed as amount of 2or 3-MCPD that can be released from 2- or 3-MCPD-FE. These methods require only a small number of analytical and internal standards.

The aim of current work was studying the formation of 3-MCPD-FE and its isomer 2-MCPD-FE during thermal treatment of high oleic sunflower oil (HOSO) in presence of different types of chlorine sources. Five different chlorine-containing salts were investigated: $\mathrm{NaCl}, \mathrm{KCl}, \mathrm{CaCl}_{2}$, $\mathrm{NH}_{4} \mathrm{Cl}$ and $\mathrm{FeCl}_{3}$, which can occur in foods. Moreover, $\mathrm{KCl}$ and $\mathrm{CaCl}_{2}$ are permitted as food additives in the European Union, E508 and E509, respectively [26]. The experiments were performed under laboratory conditions.

\section{Materials and methods}

\subsection{Chemicals and solvents}

Diethyl ether, ethyl acetate, n-hexane and HPLC-grade water were obtained from VWR (Debrecen, Hungary). Toluene, iso-hexane, sodium bromide, phenylboronic acid (PBA), and the four different chlorine containing salts (calcium chloride $/ \mathrm{CaCl}_{2}$, potassium chloride $/ \mathrm{KCl}$, ammonium chloride $/ \mathrm{NH}_{4} \mathrm{Cl}$, and ferric chloride $/ \mathrm{FeCl}_{3}$ ) were obtained from Merck (Budapest, Hungary). Methanol, sodium hydroxide, and anhydrous sodium sulphate were purchased from Reanal Laborvegyszer (Budapest, Hungary). 1,2-Bispalmitoyl-3-chloropropanediol- $\mathrm{d}_{5}$ and 1,3-Bis-palmitoyl2-chloropropanediol- $\mathrm{d}_{5}$ internal standards were obtained from Chiron AS (Trondheim, Norway). All reagents and chemicals were of analytical grade. Sodium chloride/ $\mathrm{NaCl}$ as table salt was purchased from the local market.

\subsection{Samples}

Refined high oleic sunflower oil (HOSO) was supplied by Bunge Limited (Bunge Zrt. Hungary).

\subsection{Methods}

For the thermal experiments $300 \mathrm{~g}$ of refined high oleic sunflower oil with $0.1 \%\left(0.3 \mathrm{~g}\right.$ by $\mathrm{NH}_{4} \mathrm{Cl}$ and $\left.\mathrm{FeCl}_{3}\right)$ or $3 \%$ ( $9 \mathrm{~g}$ by $\mathrm{NaCl}, \mathrm{KCl}$ and $\mathrm{CaCl}_{2}$ ) chlorine compound in a $600 \mathrm{ml}$ beaker was pre-heated in microwave-oven, then heated up to $180{ }^{\circ} \mathrm{C}$ on hot plate, magnetic stirring. The oil was kept gently stirred at $175-180{ }^{\circ} \mathrm{C}$ for 8 hours, sampled at $\mathrm{T}_{0}$ (reaching $175^{\circ} \mathrm{C}$ ), 1, 2, 4, 6 and 8 hours. Two parallel experiments were conducted for each salt and for the reference without any added salt.

The quantity of 2-MCPD-FE and 3-MCPD-FE was determined by Official AOCS Cd 29b-13 Method [27]. This method is used for determination of 2- and 3-MCPD fatty acid esters and glycidol fatty acid esters in edible oils and fats (in this study we examined only 2- and 3-MCPD-FE). The method is based on alkaline-catalyzed ester cleavage, and derivatization of free diols with PBA. These derivatives are measured by GC/MS coupled system (Agilent 6890 coupled with 5973) in SIM (selected ion monitoring) mode. Deuterated internal standards were used for determination. Characteristic ions for derivatised MCPD- $\mathrm{d}_{5}$ at m/z 150 and 201, for MCPD at 147 and 196; quantification was based on the ratio of $\mathrm{m} / \mathrm{z}=201-\mathrm{m} / \mathrm{z}=196$. SIM chromatogram of a sample is shown in Fig. 1. For 2- and $3-\mathrm{MCPD}$, the limit of detection was $0.03 \mathrm{mg} / \mathrm{kg}$, and the limit of quantification was $0.1 \mathrm{mg} / \mathrm{kg}$ based on previous experiments (data are not shown). 


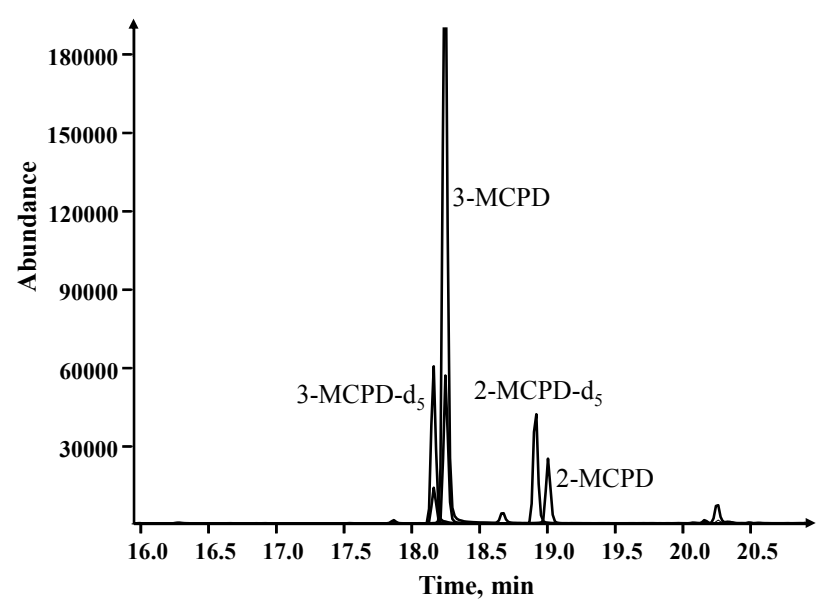

Fig. 1 SIM chromatogram (for derivatised 2- and 3-MCPD- $\mathrm{d}_{5}$ $\mathrm{m} / \mathrm{z}=150,201$; and for derivatised 2- and 3-MCPD m/z=147, 196) of a sample by GC/MS

\section{Results}

The results are expressed as mean of the two experiments for each applied salt and the reference without salt (Figs. 2-5). The raw material contained 2-MCPD-FE and 3-MCPD-FE under the limit of quantification $(<\mathrm{LOQ}=0.1 \mathrm{mg} / \mathrm{kg})$. During the thermal treatment of the refined high oleic sunflower oil without added chlorine salts, very small increase in 3-MCPD-FE content can be noticed, only a low level of $0.3 \mathrm{mg} / \mathrm{kg}$ was detected after $4-8 \mathrm{~h}$ of thermal treatment, as shown in Fig. 2. The concentration of 2-MCPD-FE did not reach the LOQ during the reaction time.

In presence of different chlorine salts 2-MCPD-FE and 3-MCPD-FE formed in different amounts depending on the salt type and heating time. Despite of the high dosage (3\%) of $\mathrm{NaCl}$ and $\mathrm{KCl}$, these chlorine salts resulted the smallest increase in both MCPD-FE content. $\mathrm{KCl}$ provoked about 1.5-2 times higher 3-MCPD-FE level than the table salt. The dynamics of formation was also different. In case of potassium chloride the concentration of 3-MCPD-FE showed a maximum point during the thermal treatment at about $4 \mathrm{~h}$. After this point the concentration decreased by about $10 \%$ until the end of the process. With $\mathrm{NaCl}$ continuous increase until the end of the experiment was found. The rate of increase reduced between 6 and $8 \mathrm{~h}$, showing that a maximum value could have been expected after $8 \mathrm{~h}$. The level of 2-MCPD-FE did not reach the LOQ in the first 2 hours during the experiment with $\mathrm{NaCl}$. At 4, 6 and 8 hour, the 2-MCPD-FE content generated by $\mathrm{KCl}$ was about 2.02.5 times higher than by $\mathrm{NaCl}$. The dynamics of formation was the same for the two salts with continuous increase.

Adding $3 \% \mathrm{CaCl}_{2}$ generated 20-30 times higher increase in 2-MCPD-FE and 3-MCPD-FE content than $\mathrm{NaCl}$.

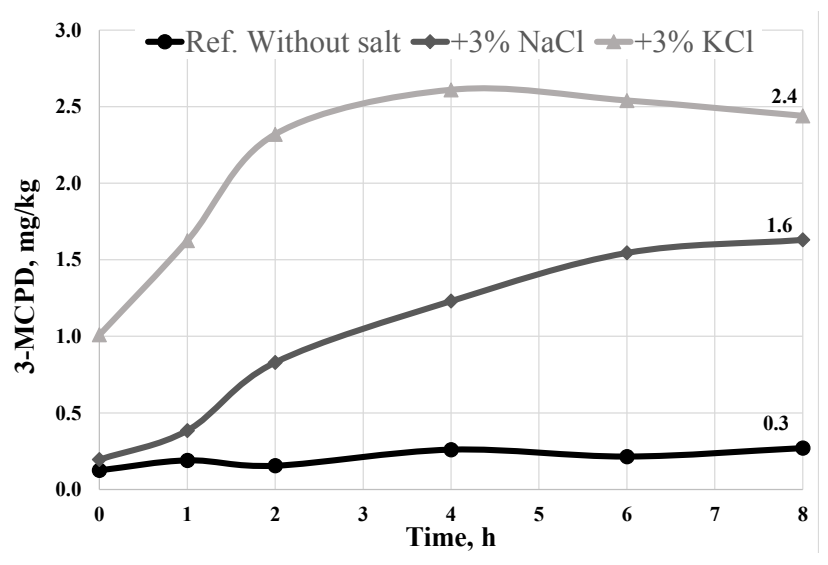

Fig. 2 Formation of 3-MCPD esters during the thermal experiments with different salts (Reference test without salt; with $3 \% \mathrm{NaCl}$; with $3 \% \mathrm{KCl}$ )

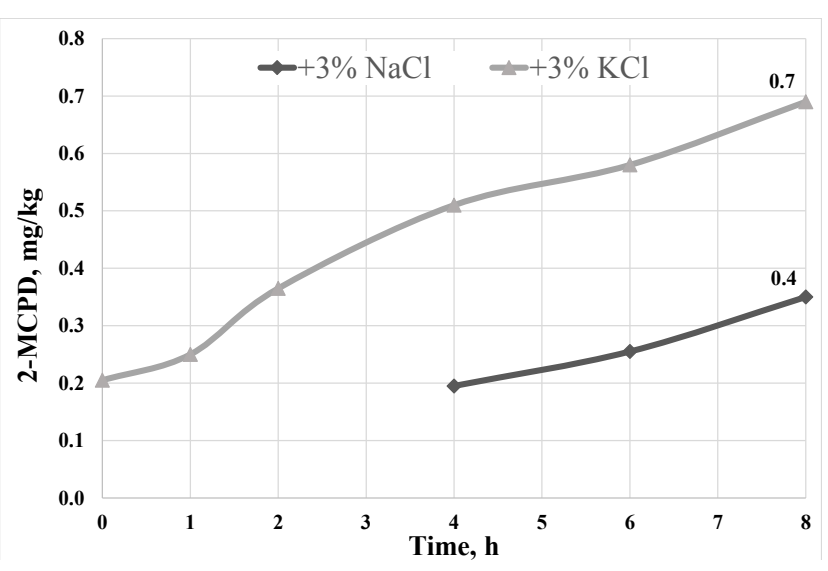

Fig. 3 Formation of 2-MCPD esters during the thermal experiments with different salts (with $3 \% \mathrm{NaCl}$; with $3 \% \mathrm{KCl}$ )

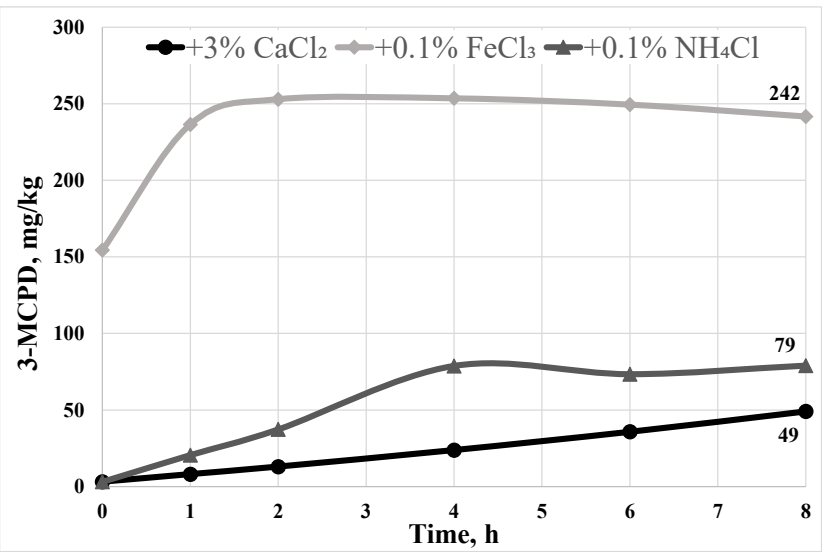

Fig. 4 Formation of 3-MCPD esters during the thermal experiments with different salts (with $3 \% \mathrm{CaCl}_{2}$; with $0.1 \% \mathrm{FeCl}_{3}$; with $0.1 \% \mathrm{NH}_{4} \mathrm{Cl}$ )

After 8 hours about $9 \mathrm{mg} / \mathrm{kg}$ 2-MCPD-FE and about $50 \mathrm{mg} / \mathrm{kg} 3$-MCPD-FE was measured, and the concentration of both increased steadily as in case of $\mathrm{NaCl}$. Applying $\mathrm{NH}_{4} \mathrm{Cl}(0.1 \%)$ caused even 1.5-2.0 times higher 2- and 3-MCPD-FE concentration than the $3 \%$ $\mathrm{CaCl}_{2}$. After increasing to $79 \mathrm{mg} / \mathrm{kg}$ during 4 hours, the 


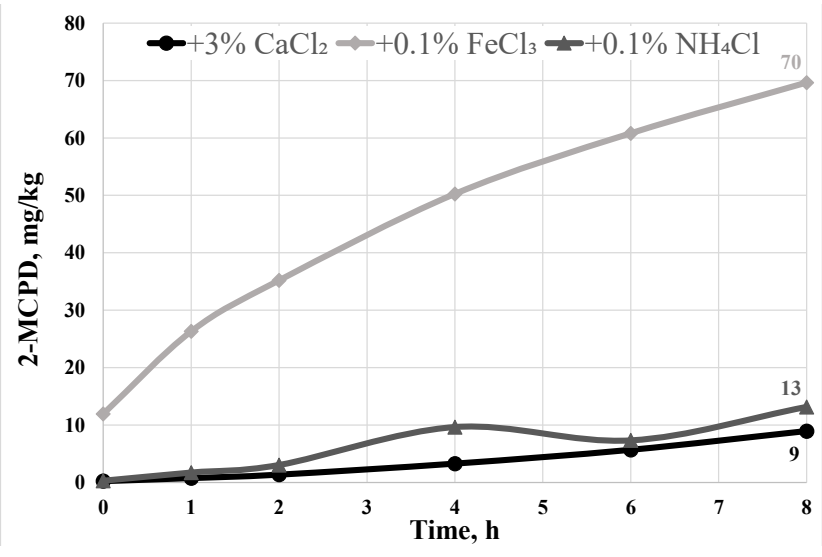

Fig. 5 Formation of 2-MCPD esters during the thermal experiments with different salts (with $3 \% \mathrm{CaCl}_{2}$; with $0.1 \% \mathrm{FeCl}_{3}$; with $0.1 \% \mathrm{NH}_{4} \mathrm{Cl}$ )

3-MCPD-FE content stagnated in the remaining time of the test (4-8 h). The 2-MCPD-FE content showed increasing tendency till $13 \mathrm{mg} / \mathrm{kg}$.

With $0.1 \% \mathrm{FeCl}_{3}$, the level of MCPD-FE formation was substantially faster and higher than in the case of the other salts. $\mathrm{FeCl}_{3}$ catalyzed 3-MCPD-FE formation, more than $100 \mathrm{mg} / \mathrm{kg}$ was observed already during the heat up period. The concentration reached about $250 \mathrm{mg} / \mathrm{kg}$ at 2 hours, and has stagnated for two more hours, and then slight decrease was noticed until the end of the treatment. The formation of 2-MCPD-FE showed different dynamics, the concentration increased steadily until the end of the experiment, reaching almost $70 \mathrm{mg} / \mathrm{kg}$.

During the heating period to $175^{\circ} \mathrm{C}$, increase in 2- and 3-MCPD-FE content was already observed, especially in the case of $\mathrm{KCl}$ and $\mathrm{FeCl}_{3}$, moreover 3-MCPD-FE content reached maximum value during the 8-hour heating by both salts. Generally, most of the contaminants formed during the first 2-4 hours of treatment in every experiment, as shown in Table 1.

The ratio of 3-MCPD-FE/2-MCPD-FE is presented on Fig. 6. Applying $\mathrm{KCl}$ and $\mathrm{NH}_{4} \mathrm{Cl}$ in the first $1-2$ hours the

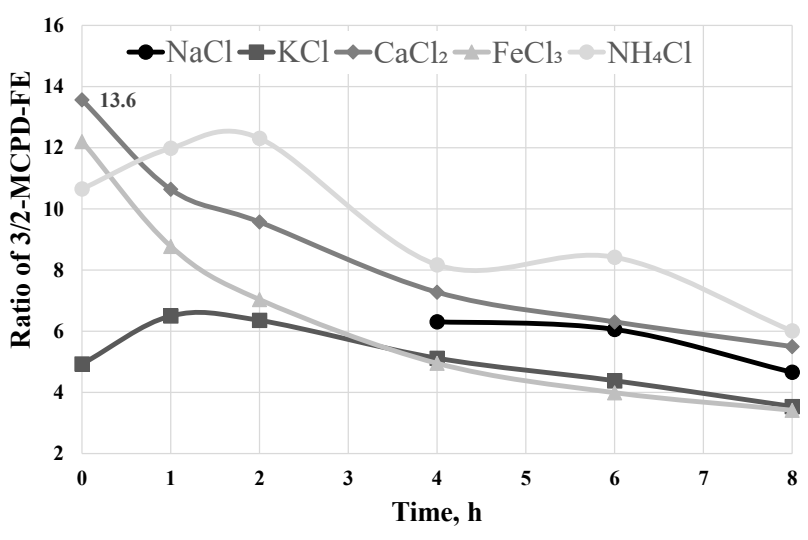

Fig. 6 Ratio of 3/2-MCPD-FE during the thermal experiments with different salts (with $3 \% \mathrm{NaCl}$, with $3 \% \mathrm{KCl}$,with $3 \% \mathrm{CaCl}_{2}$; with $0.1 \% \mathrm{FeCl}_{3}$; with $0.1 \% \mathrm{NH}_{4} \mathrm{Cl}$ )

ratio increased, reached maximum (6 and 12 respectively) and then decreased during the rest of frying time. With $\mathrm{FeCl}_{3}$ and $\mathrm{CaCl}_{2}$ the ratio could already reach the maximum during the heat up period, therefore we found continuous reduction during frying. In case of $\mathrm{NaCl}$ the maximum ratio should fall between 2 and 4 hours, as at 2 hours no 2-MCPD-FE was detected yet, while at 4 hours the ratio already stagnated and then started decreasing. All in all, the maximum ratio was the highest and appeared the earliest with salts with the highest catalytic effect $\left(\mathrm{FeCl}_{3}, \mathrm{CaCl}_{2}\right.$ and $\left.\mathrm{NH}_{4} \mathrm{Cl}\right)$.

\section{Discussion}

The presence of MCPD-FE, especially 3-MCPD-FE in vegetable oils during the refining process was examined exhaustively in previous studies [28, 29]. The formation of MCPD-FE was verified in fat containing food and food ingredients treated at high temperature as well [17-19]. Therefore the examination of frying process in presence of different chlorine sources is well-established. Moreover because of the fat uptake of the fried food, a clear carry-over of these contaminants can be assumed, which was proved before [30].

Table 12 - MCPD-FE and 3-MCPD-FE content at $\mathrm{T}_{0}$, and after 2-8h frying, in percentage of the value after $8 \mathrm{~h}$ treatment

\begin{tabular}{|c|c|c|c|c|c|c|c|c|c|c|}
\hline & \multicolumn{10}{|c|}{ Ratio \% } \\
\hline & \multicolumn{2}{|c|}{$\mathrm{T}_{0}$} & \multicolumn{2}{|c|}{$2 \mathrm{~h}$} & \multicolumn{2}{|c|}{$4 \mathrm{~h}$} & \multicolumn{2}{|c|}{$6 \mathrm{~h}$} & \multicolumn{2}{|c|}{$8 \mathrm{~h}$} \\
\hline & 3-MCPD & 2-MCPD & 3-MCPD & 2-MCPD & 3-MCPD & 2-MCPD & 3-MCPD & 2-MCPD & 3-MCPD & 2-MCPD \\
\hline Without salt & 46.3 & - & 57.4 & - & 96.3 & - & 79.6 & - & 100.0 & - \\
\hline$+3 \% \mathrm{NaCl}$ & 12.0 & - & 50.9 & - & 75.5 & 55.7 & 94.8 & 72.9 & 100.0 & 100.0 \\
\hline$+3 \% \mathrm{KCl}$ & 41.4 & 29.7 & 95.1 & 52.9 & 107.0 & 73.9 & 104.1 & 84.1 & 100.0 & 100.0 \\
\hline$+3 \% \mathrm{CaCl}_{2}$ & 6.4 & 2.6 & 26.5 & 15.2 & 48.5 & 36.7 & 72.9 & 63.5 & 100.0 & 100.0 \\
\hline$+0.1 \% \mathrm{FeCl}_{3}$ & 61.4 & 17.2 & 104.2 & 50.5 & 104.6 & 72.2 & 102.0 & 87.3 & 100.0 & 100.0 \\
\hline$+0.1 \% \mathrm{NH}_{4} \mathrm{Cl}$ & 3.9 & 2.2 & 47.2 & 23.1 & 99.7 & 73.4 & 92.9 & 66.3 & 100.0 & 100.0 \\
\hline
\end{tabular}


In our investigation even the most commonly used $\mathrm{NaCl}$ provoked measurable increase in 3-MCPD-FE level during 8-hour heating experiment. Other studies also reported the effect of $\mathrm{NaCl}$ on the formation of 3-MCPD-FE [22, 31]. Wong et al. [32, 33], showed in their studies the ability of $\mathrm{NaCl}$ for 3-MCPD-FE formation by soaking potato chips and chicken breast in different concentrations of $\mathrm{NaCl}$ solution prior to frying. They observed that higher concentration of $\mathrm{NaCl}$ in the soaking solution resulted higher concentration of 3-MCPD-FE in the oil. Calta et al. [23] concluded similarly in food processing simulation, as well. Wong et al. [33] also discovered that increasing the number of frying cycles caused partial decomposition (30-70\%) of 3-MCPD-FE, during frying of potato chips using $0,1,3$ or $5 \% \mathrm{NaCl}$ solution for soaking; however, the 3-MCPD-FE content was higher in the raw material. Frying of chicken breast showed the opposite: increasing the number of frying cycles increased the 3-MCPD-FE content [32]. This observation proves the influence of the food matrices. In our study in case of $3 \% \mathrm{NaCl}, 3-\mathrm{MCPD}-\mathrm{FE}$ content did not achieved a decreasing phase, but with other salts stagnation or reduction was recognized.

Reduction of 3-MCPD-FE content was reported in deodorization studies as well. Ermacora and Hrncirik [34] noticed the thermal degradation of 3-MCPD-FE in model system simulating deodorization, at $180^{\circ} \mathrm{C}$ the degree of decline was $30 \%$ after $24 \mathrm{~h}$ treatment. Similar results were obtained by Pudel et al. [35] with 4-6 hour long experiments at 200 and $240{ }^{\circ} \mathrm{C}$. During frying experiments of Ben Hammouda et al. [36] 30-50 \% degradation was observed after $16 \mathrm{~h}$ of thermal process.

As we described, all the examined salts caused increase in 3-MCPD-FE content of the oil, the level of change was very different depending on the type of the salt. In the study of Zhang et al. [37] $\mathrm{NaCl}, \mathrm{KCl}$ and $\mathrm{FeCl}_{3}$ promoted the formation of the contaminants from diglycerides at $240{ }^{\circ} \mathrm{C}$, but $\mathrm{CaCl}_{2}$ did not. At lower temperature $\left(120^{\circ} \mathrm{C}\right)$ only $\mathrm{FeCl}_{3}$ showed catalytic effect. The same experiments with triglycerides were repeated by this research team, and the results showed that only $\mathrm{FeCl}_{3}$ could form 3-MCPD-FE at 120 and $240{ }^{\circ} \mathrm{C}, \mathrm{NaCl}, \mathrm{KCl}$ and $\mathrm{CaCl}_{2}$ could not [38]. They proved that $\mathrm{Fe}^{3+}$ promotes radical generation under the experimental conditions (high temperature and low moisture content), and the chlorine in $\mathrm{FeCl}_{3}$ can immediately react with these radical intermediates to form 3-MCPD-FE. In the applied model reactions with analytical grade reagents the other examined chlorine salts did not support 3-MCPD-FE formation.
To the contrary, in our experiments we used real oil matrix, containing not only triglycerides, but also a numerous minor components, which might influence the catalytic effect of chlorine salts. Nevertheless, the strong catalytic effect of $\mathrm{FeCl}_{3}$ was verified in both case, as in research of Kuhlmann [31] and Li et al. [39], as well.

The ratio of 3/2-MCPD was presented in some studies before, the value ranged from 1.7:1 to $5: 1$ [16, 40, 41]. Ermacora and Hrncirik [34] found that one of the degradation pathways for 3-MCPD-FE is the isomerization to 2-MCPD-FE. Similarly, Kuhlmann [40] explained the decrease of the ratio of 3/2-MCPD-FE with isomerization, while the overall MCPD-FE was increasing proportionally to the temperature increase in the deodorization experiments. Our results support the isomerization of 3-MCPD-FE to 2-MCPD-FE. The increase of 2-MCPD-FE content was steadily almost by all of the salts, while the concentration of 3-MCPD-FE stagnated or decreased during frying. It may be explained with the different availability of the carbon atoms on the glycerol backbone. The sn-2 position is less available for the chlorine than the sn-1 and sn-3, so in the first part of the thermal treatment the formation of 3-MCPD-FE is faster. However 2-MCPD where the chlorine is bonded to sn-2 carbon is more stable than 3-MCPD where the chlorine is in external position.

The formation of 3-MCPD-FE (and 2-MCPD-FE) at the beginning of the thermal treatment is one of our most important observations, and it is comparable with previous studies, not necessarily dealing with frying process. De Kock et al. [21] concluded similarly on 3-MCPD-FE formation during deodorization of vegetable oils (2-MCPD-FE was not examined).

\section{Conclusion}

Present investigation showed the effect of different chlorine salts on the formation of 3-MCPD-FE and 2-MCPD-FE at temperature of frying in high oleic sunflower oil. The 2-MCPD-FE content in the samples was always substantially lower than the 3-MCPD-FE content. Based on the results $\mathrm{FeCl}_{3}$ and $\mathrm{NH}_{4} \mathrm{Cl}$ expressed the strongest catalytic effect. The stable salts had magnitudes lower influence. Among these $\mathrm{KCl}$ caused significantly higher 3-MCPD-FE increase than $\mathrm{NaCl}$. The results suggest that using of table salt itself does not cause health concerns in frying. From a practical point of view the real problem is the presence of $\mathrm{FeCl}_{3}$ in the frying system. As proved in model system before, not only iron chloride but also other iron salts can catalyze the formation of MCPD-FE 
if chlorine source is available in the system. It can be assumed that it works in the same way in real oil matrices. We concluded that in case of salts with stronger catalytic effect MCPD-FE noticeably increased already during the heat-up period, as well. The effect of short heating times $(0-1 h)$ and lower concentration $(<0.1 \%)$ of the most effective salt $\left(\mathrm{FeCl}_{3}\right)$ needs further study.

\section{References}

[1] IARC (International Agency for Research on Cancer) 3-Monochloro-1,2-propanediol, In: "Some Chemicals Present in Industrial and Consumer Products, Food and Drinking-water (Vol. 101)", International Agency for Research on Cancer, Lyon, France, 2013, pp. 349-374.

[2] JECFA (Joint FAO/WHO Expert Committee on Food Additives) "Contaminants - Chloropropanols", In: Evaluation Of Certain Food Additives and Contaminants: Fifty-seventh report of the Joint FAO/WHO Expert Committee on Food Additives, World Health Organization, Geneva, Switzerland, 2002, pp. 114-118.

[3] EC (European Commission) "Food Science and Techniques Reports of the Scientific Committee for Food (Thirty-sixth series) Reports of the Scientific Committee for Food", Office for Official Publications of the European Communities, Luxembourg, pp. 31-33, 1997.

[4] EFSA Panel on Contaminants in the Food Chain (CONTAM) "Update of the risk assessment on 3-monochloropropanediol and its fatty acid esters", EFSA Journal, 16, article ID: 5083, 2018. https://doi.org/10.2903/j.efsa.2018.5083

[5] JECFA (Joint FAO/WHO Expert Committee on Food Additives) "Contaminants - 3-MCPD esters and 3-MCPD", In: Evaluation Of Certain Food Additives and Contaminants: Eighty-third report of the Joint FAO/WHO Expert Committee on Food Additives, World Health Organization, Geneva, Switzerland, 2017, pp. 90-106.

[6] Abraham, K., Appel, K. E., Berger-Preiss, E., Apel, E., Gerling, S., Mielke, H., Creutzenberg, O., Lampen, A. "Relative oral bioavailability of 3-MCPD from 3-MCPD fatty acid esters in rats", Archives of Toxicology, 87(4), pp. 649-659, 2013.

https://doi.org/10.1007/s00204-012-0970-8

[7] Bundesinstitut für Risikobewertung (BfR - German Federal Institute for Risk Assessment) "3-MCPD-, 2-MCPD- GlycidylFettsäureester in Lebensmitteln: EFSA und BfR sehen Gesundheitsrisiko vor allem für jüngere Bevölkerungsgruppen" Umfassende Bewertung auf Basis aktueller Daten aus 23 EU-Mitgliedstaaten vorgelegt, Mitteilung Nr. 020/2016 des BfR vom (Frequently asked questions regarding the contamination of foods with 3-MCPD, 2-MCPD and glycidyl fatty acid esters), 07. July 2016

[8] Velísek, J., Davídek, J., Hajslová, J., Kubelka, V., Janícek, G., Mánková, B. "Chlorohydrins in protein hydrolysates", Zeitschrift für Lebensmittel-Untersuchung und -Forschung, 167(4), pp. 241244, 1978.

https://doi.org/10.1007/BF01135595

[9] EC (European Commission) "COMMISSION REGULATION No 1881/2006 of 19 December 2006 setting maximum levels for certain contaminants in foodstuffs", 2006.

\section{Acknowledgement}

The project presented in this article is supported by the Doctoral School of Food Sciences at Szent István University (Budapest); by the Bunge EMEA Katalin Kövári R\&D Centre (Budapest); and by the European Union and co-financed by the European Social Fund (grant agreement no. EFOP-3.6.3-VEKOP-16-2017-00005).

[10] EC (European Commission) "COMMISSION REGULATION 2018/290 of 26 February 2018 amending Regulation (EC) No $1881 / 2006$ as regards maximum levels of glycidyl fatty acid esters in vegetable oils and fats, infant formula, follow-on formula and foods for special medical purposes intended for infants and young children", 2018.

[11] Becalski, A., Feng, S., Lau, B. P-Y., Zhao, T. "A pilot survey of 2- and 3-monochloropropanediol and glycidol fatty acid esters in foods on the Canadian market 2011-2013", Journal of Food Composition and Analysis, 37, pp. 58-66, 2015.

https://doi.org/10.1016/j.jfca.2014.09.002

[12] Crews, C., Hough, P., Brereton, P. Harvey, D., MacArthur, R., Matthews, W. "Survey of 3-monochloropropane-1,2-dio 1 (3MCPD) in selected food groups, 1999-2000", Food Additives and Contaminants, 19(1), pp. 22-27, 2002.

https://doi.org/10.1080/02652030110085395

[13] Chung, S. W. C., Kwong, K. P., Yau, J. C. W., Wong, A. M. C., Xiao, Y. "Chloropropanols levels in foodstuffs marketed in Hong Kong", Journal of Food Composition and Analysis, 21(7), pp. 569-573, 2008.

https://doi.org/10.1016/j.jfca.2008.04.010

[14] Carlson, F. K. "Deodorization", In: Hui, Y. H. (ed.) Bailey’s industrial oil and fat products. Edible oil and fat products: Processing technology, Vol. 4, John Wiley \& Sons INC, New York, USA, 1996, pp. 339-391.

[15] O’Brien, R. D. "Fats and Oils: Formulating and Processing for Applications", CRC Press, Boca Raton, FL, USA, 2008.

[16] Destaillats, F., Craft, B. D., Sandoz, L., Nagy, K. "Formation mechanisms of Monochloropropanediol (MCPD) fatty acid diesters in refined palm (Elaeis guineensis) oil and related fractions", Food Additives and Contaminants: Part A, 29(1), pp. 29-37, 2011. https://doi.org/10.1080/19440049.2011.633493

[17] Crews, C., Brereton, P., Davies, A. "The effects of domestic cooking on the levels of 3-monochloropropanediol in foods", Food Additives and Contaminants, 18(4), pp. 271-280, 2001. https://doi.org/10.1080/02652030120064

[18] Svejkovská, B., Doležal, M., Velíšek, J. "Formation and Decomposition of 3-Chloropropane-1,2-diol Esters in Models Simulating Processed Foods", Czech Journal of Food Sciences, 24(4), pp. 172-179, 2006. https://doi.org/10.17221/3314-CJFS

[19] Merkle, S., Ostermeyer, U., Rohn, S., Karl, H., Fritsche, J. "Formation of Ester Bound 2- and 3-MCPD and Esterified Glycidol in Deep-Fried and Pickled Herring Products", European Journal of Lipid Science and Technology, 120(7), article ID: 1700464, 2018. https://doi.org/10.1002/ejlt.201700464 
[20] Zhang, Q., Saleh, A. S. M., Chen, J., Shen, Q. "Chemical alterations taken place during deep-fat frying based on certain reaction products: A review", Chemistry and Physics of Lipids, 165(6), pp. 662-681, 2012.

https://doi.org/10.1016/j.chemphyslip.2012.07.002

[21] De Kock, J., Papastergiadis, A., De Greyt, W. "Technological Solutions and Developments in Edible Oil Processing to Minimize Contaminants in Various Oils and Fats", presented at $5^{\text {th }}$ Leipzig Symposium 'Processing and Analytics: How does co-operation work in Practice' Leipzig, Germany, March 9-10, 2016.

[22] Zhou, H., Jin, Q., Wang, X., Xu, X. "Effects of temperature and water content on the formation of 3-chloropropane-1,2-diol fatty acid esters in palm oil under conditions simulating deep fat frying", European Food Research and Technology, 238(3), pp. 495501, 2014. https://doi.org/10.1007/s00217-013-2126-3

[23] Calta, P., Velíšek, J., Doležal, M., Hasnip, S., Crews, C., Réblová, Z. "Formation of 3-chloropropane-1,2-diol in systems simulating processed foods", European Food Research and Technology, 218(6), pp. 501-506, 2004. https://doi.org/10.1007/s00217-003-0865-2

[24] Ermacora, A., Hrncirik, K. "Indirect Detection techniques for MCPD Esters and Glycidyl Esters", In: MacMahon, S. (ed.) Processing contaminants in edible oils MCPD and Glycidyl Esters, AOCS Press, Illinois, 2014, pp. 57-90.

https://doi.org/10.1016/C2015-0-02406-6

[25] MacMahon, S. "Direct Detection Techniques for MCPD Esters", In: MacMahon, S. (ed.) Processing contaminants in edible oils MCPD and Glycidyl Esters, AOCS Press, Illinois, 2014, pp. 121-167. https://doi.org/10.1016/C2015-0-02406-6

[26] EC (European Commission) "COMMISSION REGULATION (EU) No 1129/2011 of 11 November 2011 amending Annex II to Regulation (EC) No 1333/2008 of the European Parliament and of the Council by establishing a Union list of food additives", 2011.

[27] AOCS (American Oil Chemists' Society) Official Method Cd 29b-13 "Determination of Bound Monochloropropanediol(MCPD-) and Bound 2,3-epoxy-1-propanol (glycidol) by Gas Chromatography/Mass Spectrometry (GC/MS)", In: Official Methods and Recommended Practices of the AOCS, Urbana, Illinois, 2013.

[28] Franke, K., Strijowski, U., Fleck, G., Pudel, F. "Influence of chemical refining process and oil type on bound 3-chloro-1,2-propanediol contents in palm oil and rapeseed oil", LWT - Food Science and Technology, 42(10), pp. 1751-1754, 2009. https://doi.org/10.1016/j.lwt.2009.05.021

[29] Matthäus, B., Pudel, F., Fehling, P., Vosmann, K., Freudenstein, A. "Strategies for the reduction of 3-MCPD esters and related compounds in vegetable oils", European Journal of Lipid Science and Technology, 113(3), pp. 380-386, 2011. https://doi.org/10.1002/ejlt.201000300

[30] Arisseto, A. P., Marcolino, P. F. C., Augusti, A. C., Scaranelo, G. R., Berbari, S. A. G., Miguel, A. M. R. O., Morgano, M. A., Vicente, E. "Contamination of Fried Foods by 3-Monochloropropane-1,2-diol Fatty Acid Esters During Frying", Journal of the American Oil Chemists' Society, 94(3), pp. 449-455, 2017. https://doi.org/10.1007/s11746-017-2951-9
[31] Kuhlmann, J. "MCPD and Glycidol in Edible Oils - Post Refining Formation, Decomposition and Analysis", presented at 11th Euro Fed Lipid Congress, Antalya, Turkey, Oct. 27-30, 2013.

[32] Wong, Y. H., Lai, O. M., Abas, F., Nyam, K. L., Nehdi, I. A., Muhamad, H., Tan, C. P. "Factors Impacting the Formation of 3-MCPD Esters and Glycidyl Esters During Deep Fat Frying of Chicken Breast Meat", Journal of the American Oil Chemists' Society, 94(6), pp. 759-765, 2017. https://doi.org/10.1007/s11746-017-2991-1

[33] Wong, Y. H., Muhamad, H., Abas, F., Lai, O. M., Nyam, K. L., Tan, C. P. "Effects of temperature and $\mathrm{NaCl}$ on the formation of 3-MCPD esters and glycidyl esters in refined, bleached and deodorized palm olein during deep-fat frying of potato chips", Food Chemistry, 219, pp. 126-130, 2017. https://doi.org/10.1016/j.foodchem.2016.09.130

[34] Ermacora, A., Hrncirik, K. "Study on the thermal degradation of 3-MCPD esters in model systems simulating deodorization of vegetable oils", Food Chemistry, 150, pp. 158-163, 2014. https://doi.org/10.1016/j.foodchem.2013.10.063

[35] Pudel, F., Benecke, P., Fehling, P., Freudenstein, A., Matthäus, B., Schwaf, A. "On the necessity of edible oil refining and possible sources of 3-MCPD and glycidyl esters", European Journal of Lipid Science and Technology, 113(3), pp. 368-373, 2011. https://oi.org/10.1002/ejlt.201000460

[36] Ben Hammouda, I., Zribi, A., Ben Mansour, A., Matthäus, B., Bouaziz, M. "Effect of deep-frying on 3-MCPD esters and glycidyl esters contents and quality control of refined olive pomace oil blended with refined palm oil", European Food Research and Technology, 243(7), pp. 1219-1227, 2017. https://doi.org/10.1007/s00217-016-2836-4

[37] Zhang, X., Gao, B., Qin, F., Shi, H., Jiang, Y., Xu, X., Yu, L. L. "Free Radical Mediated Formation of 3-Monochloropropanediol (3-MCPD) Fatty Acid Diesters", Journal of Agricultural and Food Chemistry, 61(10), pp. 2548-2555, 2013.

https://doi.org/10.1021/jf305252q

[38] Zhang, Z., Gao, B., Zhang, X., Jiang, Y., Xu, X., Yu, L. L. "Formation of 3-Monochloro-1,2-propanediol (3-MCPD) Di- and Monoesters from Tristearoylglycerol (TSG) and the Potential Catalytic Effect of $\mathrm{Fe}^{2+}$ and $\mathrm{Fe}^{3+"}$, Journal of Agricultural and Food Chemistry, 63(6), pp. 1839-1848, 2015. https://doi.org/10.1021/j55061216

[39] Li, C., Zhou, Y., Zhu, J., Wang, S., Nie, S., Xie, M. "Formation of 3-chloropropane-1,2-diol esters in model systems simulating thermal processing of edible oil", LWT - Food Science and Technology, 69, pp. 586-592, 2016. https://doi.org/10.1016/j.1wt.2016.02.012

[40] Kuhlmann, J. "Determination of bound 2,3-epoxy-1-propanol (glycidol) and bound monochloropropanediol (MCPD) in refined oils", European Journal of Lipid Science and Technology, 113(3), pp. 335-344, 2011. https://doi.org/10.1002/ejlt.201000313

[41] Ermacora, A., Hrncirik K. "Influence of oil composition on the formation of fatty acid esters of 2-chloropropane-1,3-diol (2-MCPD) and 3-chloropropane-1,2-diol (3-MCPD) under conditions simulating oil refining", Food Chemistry, 161, pp. 383-389, 2014. https://doi.org/10.1016/j.foodchem.2014.03.130 